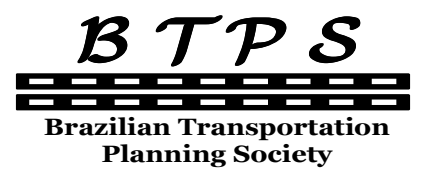

Journal of Transport Literature

Vol. 7, n. 1, pp. 65-82, Jan 2013

Research Directory
JTL | RELIT

www.transport-literature.org ISSN 2238-1031

\title{
The exploitation of public Brazilian airports under private regime: a review of government leased and permit grants
}

\author{
[A exploração de aeródromos públicos brasileiros sob regime privado: \\ uma revisão das concessões e autorizações] \\ Fabiana Peixoto de Mello, Dorieldo Luiz dos Prazeres* \\ Queen's University, Canada, Agência Nacional de Aviação Civil (ANAC), Brazil
}

Submitted 9 Sep 2011; received in revised form 30 Jan 2012; accepted 9 Feb 2012

\begin{abstract}
This paper investigates the regulatory aspects of exploiting Brazilian public airports under private regime. The proposition is that the essential difference between leased and permit grants is the level of regulatory intervention by the Government, which then determines the legal regime to which the airport exploitation is predominantly subject to. The descriptive and exploratory methodology used is based on previous literature on airport exploitation. The results indicate that airports exploited predominantly under private regime, that is, those granted permits, are generally subject to a lighter regulatory intervention than those exploited under public regime, which are granted a lease, hence the level of necessary regulatory intervention is the main criterion for determining which type of grant shall be used for a certain airport. The conclusion also indicates that the level of regulatory intervention to which an airport is subject will depend on the value of use to the collectivity that its operations generate. The optimal granting policy is an ideal combination of types of grants directly related to the diversification of the airport services and the different levels of regulatory intervention that they require.
\end{abstract}

Key words: public airports; private airports; leased grants; permit grants; airport exploitation.

\section{Resumo}

Este trabalho investiga os aspectos regulatórios da exploração de aeroportos públicos sob regime privado no Brasil. A proposição é que a diferença essencial entre aeroportos concessionados e autorizados é o nível de intervenção regulatória pelo Governo, que então determina o regime ao qual a exploração estará sujeita. A metodologia descritiva e exploratória utilizada é baseada em literatura anterior sobre exploração aeroportuária. Os resultados indicam que aeroportos explorados predominantemente sob regime privado, isto é, os autorizados, são geralmente sujeitos a intervenção regulatória mais leve que aqueles explorados sob regime público, que são concessionados, logo o nível de intervenção regulatória é o critério principal para determinar o grau de interesse público nas operações do aeroporto. A conclusão também indica que o grau de intervenção regulatória ao qual um aeroporto estará sujeito dependerá do valor de uso para a coletividade que suas operações gerarem. A política de outorgas ótima é uma combinação de tipos de outorgas diretamente relacionada à diversificação dos serviços do aeroporto e aos graus de intervenção regulatória que eles requerem.

Palavras-Chave: aeroportos estatais; aeroportos privados; aeroportos concedidos; aeroportos autorizados; exploração.

* Corresponding Author. Email: dorieldo@gmail.com.

\section{Recommended Citation}

Mello, F. P. and Prazeres, D. L. (2013) The exploitation of public Brazilian airports under private regime: a review of government leased and permit grants. Journal of Transport Literature, vol. 7, n. 1, pp. 65-82.

- JTL/RELIT is a fully electronic, peer-reviewed, open access, international journal focused on emerging transport markets and published by BPTS - Brazilian Transport Planning Society. Website www.transport-literature.org. ISSN 2238-1031.

This paper is downloadable at www.transport-literature.org/open-access. 


\section{Introduction}

In 1990, to address the economic crisis that hit Brazil, the Brazilian Government initiated a restructuring process of the public sector in order to strengthen investments and technology and to improve the performance of public services. This process involved granting rights to exploit public services to local and foreign non-state owned companies. The regulatory framework for the restructuring process had been set out in the 1988 Federal Constitution and its amendments.

The Brazilian airport infrastructure crisis added to the country's commitment to host two international events that urge the restructuring of the industry, which so far has been almost totally dependent on governmental undertakings. Private sector entities have been publicly disclosing their interest in their participation of public bids of grants to exploit existing airports as well as in obtaining permits to build and exploit new greenfield airports, at their own risk.

The Federal Constitution and the ordinary law in force - Law n. 7,565, dated 1986, the Law n. 6,009, dated 1973 and Law n. 11,182, dated 2005 - state that airports are public interest facilities that can be exploited either directly by the public sector, through the Government or its state-owned undertakings, or indirectly by the private sector by means of a grant from the Federal Government.

The grant for the private sector to exploit an airport may take the form of a lease or a permit, according to the cited law. The law does not contain superfluous words pursuant to Brazilian rules of law interpretation, therefore, the fact that the law provides for two different types of grants indicates that they have different characteristics and should be used in different circumstances.

The aim of this report is to analyze the main differences between leases and permits, as well as the situations in which each should be used. The methodology was based on bibliographical research of specialized literature and from a review of the law in force. 
This work is divided into sections: Section 1 introduces the analysis; Section 2, analyzes the mechanisms to grant the exploitation of public interest services provided for in the law and their respective exploitation regimes; Section 3 examines the possibility for use of permits to grant the exploitation of airport infrastructure; Section 4 reviews the designation used by the Brazilian Aeronautical Code; Section 5 argues that the need of regulatory intervention is the criterion to determine the type of grant; Section 6 provides examples of airports exploited under private regime in Brazil and worldwide; Section 7 argues that the operational features of an airport do not influence the public interest in its exploitation; Section 8 presents different approaches to the evolution of the provision of airport services and of the different types of grants. This report is concluded with the suggestion that the Brazilian airport infrastructure crisis can be relieved through public policies that adopt multiple types of grants according to the prevailing interest in the exploitation of the airports.

\section{Types of grant and exploitation regimes}

There is no legal definition of public service in Brazilian law. The concept of public service construed by Brazilian legal experts is derived from the French doctrine of the 1950's. Public service is considered to be all the services provided directly by the Government or its entities or indirectly by non-state owned entities by means of a grant.

Article 21, Item XII, of the Brazilian Constitution enlists activities that shall be exploited directly by the Federal Government or granted to the private sector by leases or permits and airport infrastructure is among them.

The fact that an activity is enlisted as having a public service nature does not mandate it to be exploited under the public regime. The exploitation of some activities granted to the private sector may, and on occasion, should be, performed under private regime.

The Brazilian Law, by line of principle, does not acknowledge public function or public service $^{1}$, of any nature, that is not rendered by the Government or by means of a Government grant. On the other hand, according to Couto e Silva (2009), "the legal regime to which the public service activity is rendered is either entirely public, as it happens with the

\footnotetext{
${ }^{1}$ Apart from those considered essential public services, such as justice, national defense, for example.
} 
administrative services or is, in the case of commercial or industrial services, predominantly private, but mixed with public law rules."

The role of the Brazilian Government has shifted since the 1950's from managers that directly exploit the services to regulators that make the policies and audit their compliance. Acknowledging and incorporating this historical change, the European Union has updated the concept of public service, replacing it with Services of General Interest (SGI) and Services of General Economic Interest (SGEI).

According to the Treaty on the Functioning of the European Union (TFEU), SGI are activities, economic or not, deemed of general interest by the State and subjects to public service specific rules. SGEI, on the other hand, are economic activities of public interest, generally granted to exploitation by the private sector. SGEI are performed under private regime even though ruled by specific public services obligations.

The telecommunications sector pioneered incorporating private and public regimes of exploitation of public service into the Brazilian legal system. Nevertheless, electric energy and port sectors also admit to the exploitation of services under private regime, granted by permits.

The legal regime that governs the provision of public services is determined according to the type of grant for its exploitation.

Table 1 - Main differences between lease and permit

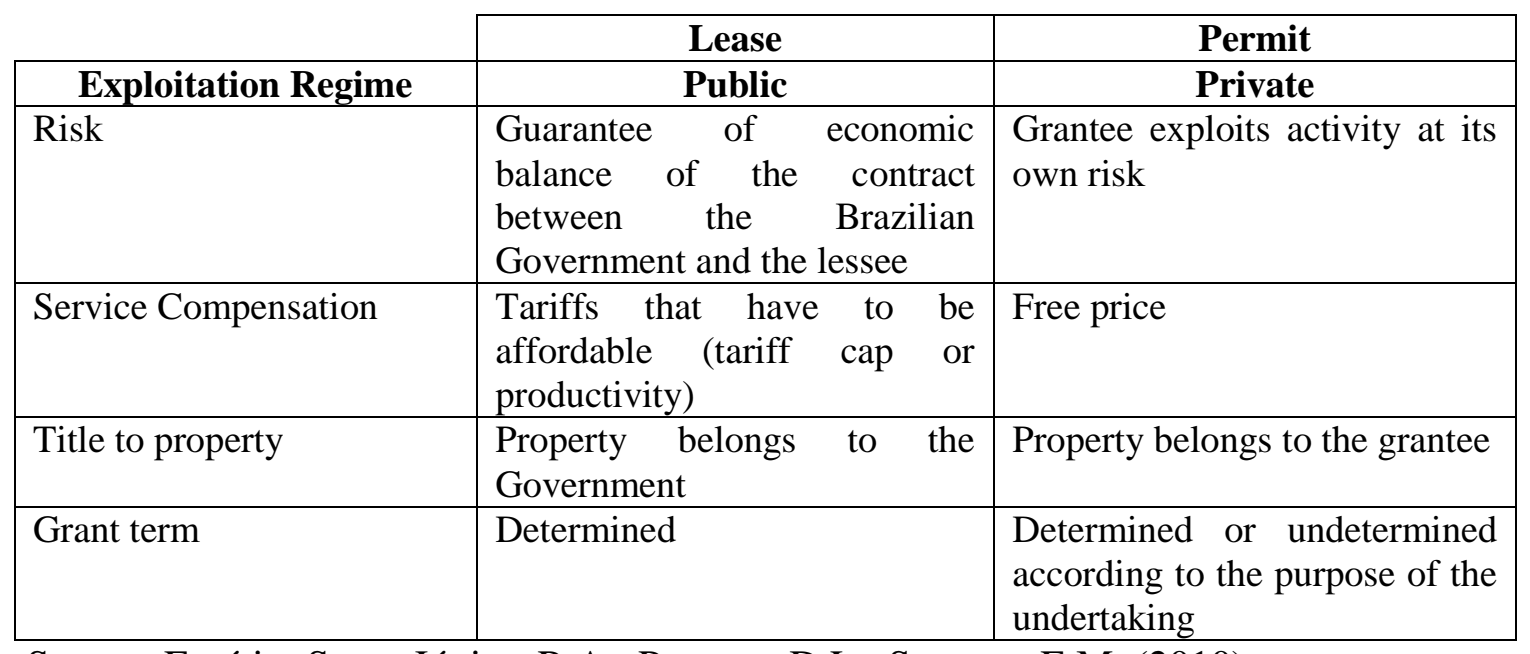

Source: Espírito Santo Júnior, R.A.; Prazeres D.L.; Santana, E.M. (2010) 


\section{The possibility of the use of permits to grant airport exploitation to the private sector}

The recent economic development Brazil is undergoing requires substantially high investments in infrastructure to meet the existing and projected lack of capacity. The investments have different ends according to the context in which the infrastructure is required. Airports built and exploited by the private sector to serve predominantly private interests but open to the public in general are a vital element of an optimal infrastructure portfolio.

The Brazilian Government does not have the capacity to bear all investments needed to support the economic growth and development, and for that reason, the level of responsibility of the Brazilian Government cannot be uniform in all projects but has to be proportional to the predominant interest in each of them. The Brazilian Government must have types of grants that allow it flexibility to exert different levels of regulatory intervention. Permits have to be used to offer legal certainty to the investments made by the private sector.

The law in force expressly allows the use of authorization as a grant of airport exploitation rights to the private sector. The Brazilian Aeronautical Code (CBA) was approved by the Brazilian law \#7.565, dated 19th December, 1986. Article 36, Item IV, of the CBA states that the exploitation of public airports may be granted by means of leases or permits. This grant shall not be confused with the authorization to build and operate airports for the exclusive use of its operators, whose services shall not to be commercially exploited. The permit to build and operate provided for in Article 36, Item IV, of the CBA relates to airports open to the public in general and that are commercially exploited. The 1986 CBA provision was emulated in Article 21, Item XII, c, of the 1988 Federal Constitution.

The legal and constitutional possibility of using permits to grant airports exploitation to private sector is acknowledged by Brazilian experts, such as: Farias (2005), Aragão (2007), Prazeres (2011) e Espírito Santo, Santana and Prazeres (2010). In developed and developing countries around the world, permits are used to grant exploitation of airports to the private sector. Foreign experts such as Kapur (1995) and Heinke \& Wei (2000) also acknowledge the use of permits to airport undertakings. 
The following chart correlates the air transport and airport services to the respective types of grant according to the rules of the CBA.

Table 2 - Grid of grant types in the Brazilian Aeronautical Code

\begin{tabular}{|c|c|c|}
\hline \multicolumn{2}{|c|}{$\begin{array}{c}\text { Public Services } \\
\text { (commercial exploitation allowed) }\end{array}$} & $\begin{array}{c}\text { Private Services } \\
\text { (commercial exploitation }\end{array}$ \\
\hline Lease & Permit & Grant not applicable \\
\hline $\begin{array}{l}\text { Regular Air Transport Services } \\
\text { (arts. } 180 \text { and 181) }\end{array}$ & $\begin{array}{c}\text { Air Tax } \\
\text { (arts. } 180 \text { and 220) } \\
\text { Specialized Air Transport } \\
\text { Services } \\
\text { (arts. } 180 \text { and 182) }\end{array}$ & $\begin{array}{c}\text { Private (exclusive) Air } \\
\text { Transport Services } \\
\text { (art. 14, } 1, \S 2 \text {, cc arts. } 177 \text { and } \\
178)\end{array}$ \\
\hline $\begin{array}{l}\text { Leased Airport Services } \\
\quad(\text { art. 36, IV) }\end{array}$ & $\begin{array}{c}\text { Permitted Airport Services } \\
\text { (art. 36, IV) }\end{array}$ & $\begin{array}{c}\text { Private (exclusive) Airport } \\
\text { Services } \\
\text { (art. 30, §2) }\end{array}$ \\
\hline
\end{tabular}

Source: Law n. 7,565, December $19^{\text {th }}, 1986(\mathrm{CBA})$

The Brazilian aviation law established different types of grants to the provision of air transport and airport services. In the case of air transport services, the type of grant was determined based on the distinction of services rendered to the exclusive benefit of its exploiter, deemed private, and the rest of the air transport services, deemed public. In the case of airport services, however, the CBA does not specify the criterion that distinguishes a leased and permitted public airport.

\section{The designations of public and private aerodromes in the Brazilian Aeronautical Code}

According to the Brazilian Aeronautical Code in force, public service is the service commercially exploited, and it can only be provided by means of a grant of the Federal Government, which may take form of a lease or of a permit. Private Service, on the other hand, is the service rendered exclusively or restrictively to the owner of the aerodrome, thus its commercial exploitation is prohibited.

Aerodromes may provide public or private services but airports are always public aerodromes. Airports are equipped with buildings and facilities to support the provision of airport services to the community and enable it for its commercial exploitation. 
The legal designation of the terms public service or private service for an aerodrome, according to the Brazilian law, is a function of its purpose or destination, and not of its ownership. The legal concept of a public or private aerodrome has no relation to the ownership of the airport or to the ownership of its operator. This elucidation is necessary because of the terms public and private and their consequential legal effects, which are often associated with the ownership of the airport or of its operator, even in the aeronautical sector.

For clarification purposes, a private aerodrome, that is, an aerodrome with restricted or exclusive use by its owner, may become a public aerodrome if it starts serving the public in general and is commercially exploited. To that effect, it has to obtain a permit and meet the technical and operational requirements set by the National Aviation Agency - ANAC. The former private aerodrome used for its owner's convenience then becomes open to the public in general, ceasing to be private, even though its ownership remains private, as taught by Pacheco (2006, p. 81).

\section{The criterion of regulatory intervention as determinant of the appropriate type of grant for airports' exploitation}

We propose that the type of grant to exploit airport infrastructure opened to the public in general will depend on the level of regulatory intervention, similarly to the criterion applied to lease or permit air transport services.

There is public interest in regulating the standards a non-state owned airport should meet to render services to the public in general, however, many non-state owned airports create additional or marginal value of use to the collectivity as a whole. Only some of them create value of use to the collectivity as a whole and when that universal value is created, it has to be guaranteed by the principles that rule the Public Administration, such as regularity, continuity, efficiency, generality, courtesy in providing the service and affordable tariffs. Hence, airports that create universal value - value to the collectivity as a whole - shall be exploited under public regime and provided grants by means of a lease. Airports that create value of use to the collectivity, but only in an additional or marginal fashion, shall be exploited predominantly under private regime and provided a permit grant. 
Therefore, leased airports services are provided on behalf of the Government because they create universal value to the country and the interest in their exploitation is predominantly public. Whereas, permitted airport services, despite serving the public in general, are economic activities provided to the collectivity for convenience and at the exploiter's (airport operator's) own risk.

Permitted airports are built, maintained and exploited to the benefit and at the risk of the private interest that prevails over the public interest. Nevertheless, there is public interest in its services to the extent that it benefits the surrounding collectivity. The benefit is not exclusive or restricted to the airport operator itself, as it happens in the private (exclusive) aerodromes, according to the designation of the CBA.

Espirito Santo Júnior, Prazeres and Santana argue that the exploitation of airport services under private regime is a means to break entry barriers and allow new entrants. Consequently, there is public interest in the provision of airport services under the private regime to create a favorable environment for competition in a market that tends to be concentrated by its own nature.

The provision of airport services under different regimes avoids unnecessary duplication of infrastructures, stimulates competition in the sector, reduces the need for intervention of the regulatory authority in the same level in all airports and reduces the governmental cost of regulation.

\section{Selected examples of airports exploited under private regime in Brazil and worldwide}

Punta Cana International Airport, originally planned and conceived to meet the Dominican Republic resorts needs of airport services is an example of an airport exploited under private regime. After nine expansions, it has become the airport with the greatest passenger movement of that country.

The Punta Cana International Airport is owned by the Punta Cana Group and is exploited by Punta Cana Resort and Club. During the high season, the airport operates 250 weekly flights, and on some weekends up to 65 international flights. Without this airport, the resort would 
not prosper; the tourism industry represents an important share of the State revenues in that region.

The Punta Cana International Airport is a public utility directly affected by commercial and industrial activities of its investors because its existence and operation are essential to the survival of the businesses it serves. It is not subject to the obligations inherent to conventional public service because the business it serves - and not the Dominican Republic's national interest - is the main reason for its existence. It would not be adequate to exploit this airport under public regime.

A similar situation is that of the Usiminas and Monte Dourado airports in Brazil, conceived predominantly to support the convenience of the grantees that exploit them. These airports also serve their surrounding communities, whether or not it is in relation to the interest of their operators. These are examples of small cities in the hinterland of Brazil, in which the businesses create economic flow as a result of their activities and, which in turn attract and develop a small urban center dependent on this flow. These airports create an additional value of use to the surrounding community but do not create a universal value of use to the country. Nevertheless, they do stimulate regional economic development; hence there is a synergy between the public and private interests, in which the private interest bears more weight.

The airport services provided at Usiminas and Monte Dourado airports have different characteristics than those provided in conventional State owned or leased airports. Airports exploited under the public regime (leased airports) provide services that meet the public interest predominantly. The contractual obligations of leased airports include adequate service, that is, services that meet conditions such as regularity, continuity, efficiency, generality, courtesy in providing and affordable tariffs.

Airports exploited under the private regime (permitted airports), on the other hand, provide services that meet the private interest predominantly, which is not to say that they conflict with the public interest.

London City airport draws attention because it was not designed to meet a specific business need but to serve a niche in the market less available or less attractive to conventional airports. Due to its limited capacity, London City Airport specializes in business aviation 
flights, international medium to long haul flights and regular commercial aviation with midsized mostly executive aircrafts. Built near the financial center of London, it provides connections to other airports or locations through helicopter transport or through alternative metropolitan transport services. Its services are more expensive than those of airports exploited under the public regime. This happens because conventional airports prioritize regular commercial aviation. In a congested market, business aviation has difficulty in operating at conventional airports and suffers from lack of capacity. The London City airport offers to business and general aviation the capacity it needs and the convenience that the sector demands.

\section{The irrelevance of capacity, function and exclusivity criteria to determine the type of grant}

A widespread error in determining demand is to assess the predominant interest in an airport based on its capacity. In order to demonstrate this point, a comparative analysis of permitted airports around the world was made. Permitted airports are those deemed to have been exploited at the risk of their investors under minimum price intervention.

Table 3 - Grid of grant types in the Brazilian Aeronautical Code

\begin{tabular}{|l|c|c|}
\hline \multicolumn{1}{|c|}{ Airport } & Country & Grantee \\
\hline Monte Dourado Airport & Brazil & Jari Celulose \\
\hline Usiminas Airport & Brazil & Usiminas \\
\hline Lanseria International Airport & South Africa & Lanseria Airport 1993 \\
\hline $\begin{array}{l}\text { London City International } \\
\text { Airport }\end{array}$ & England & London City Airport Ltd \\
\hline $\begin{array}{l}\text { Punta Cana International } \\
\text { Airport }\end{array}$ & Dominican Republic & $\begin{array}{c}\text { Punta Cana Resort and } \\
\text { Club/Grupo Punta Cana }\end{array}$ \\
\hline
\end{tabular}

\subsection{Operational Features}

The correct nature of the regime under which the airport will be exploited is determined by the predominance of the public interest over the private interest. The operational characteristics of the airports, such as the runway, terminal or apron capacity and the number of takeoffs and landings, do not distinguish the predominant interest in their exploitation. 
There are non-state owned airports exploited predominantly under private regime with great traffic density and large capacity for handling wide body aircrafts.

Table 4 - Pax Movement in Selected Private Airports - 2010

\begin{tabular}{|l|c|c|}
\hline \multicolumn{1}{|c|}{ Airport } & Country & Traffic \\
\hline Monte Dourado Airport & Brazil & 10,031 \\
\hline Usiminas Airport & Brazil & 100,148 \\
\hline Lanseria International Airport & South Africa & Unavailable \\
\hline $\begin{array}{l}\text { London City International } \\
\text { Airport }\end{array}$ & England & $2,708,582$ \\
\hline $\begin{array}{l}\text { Punta Cana International } \\
\text { Airport }\end{array}$ & Dominican Republic & $4,033,391$ \\
\hline
\end{tabular}

The Punta Cana International Airport, for example, works with two parallel taxiways, eight boarding gates, 50 check-in desks, six baggage carousels and the capability to handle an aircraft the size of a Boeing 747-400. According to the Dominican Republic Ministry of Tourism data, in 2010 the entire country received around 4.1 million passengers while the Punta Cana International Airport alone received 2 million passengers.

The infrastructure of the Punta Cana International Airport - a private airport - is far superior to the Congonhas Airport in Brazil - a public airport. The Punta Cana International Airport primarily serves the tourism industry and is privately owned and operated. The Congonhas Airport is strategic to the country and it is clearly an object of public interest because it is the second busiest airport in Brazil and is the most important connection between domestic routes. Because the operational features of the airports do not determine their main purposes or the interests that they serve primarily and are not determinant of their public or private nature or the regime under which they should be exploited.

Table 5 - Comparison between Congonhas Airport and Punta Cana International Airport

\begin{tabular}{|l|c|c|}
\hline \multicolumn{1}{|c|}{ Airport } & $\begin{array}{c}\text { Length of Longest Runway } \\
(\mathbf{m})\end{array}$ & $\begin{array}{c}\text { Annual pax movement in } \\
\mathbf{2 0 1 0} \text { (millions) }\end{array}$ \\
\hline $\begin{array}{l}\text { Punta Cana International } \\
\text { Airport }\end{array}$ & 3,110 & $4,003,391$ \\
\hline Congonhas Airport & 1,940 & $14,481,370$ \\
\hline
\end{tabular}

Source: own elaboration.

The Lanseria International Airport in South Africa is also capable of handling large aircrafts such as the Boeing 757-300 and Airbus A319. London City International Airport, however, 
cannot handle large aircrafts because of its short runway $(1.508 \mathrm{~m})$, the slope of its ramp approach and because it is subject to noise restrictions to the urban environment.

\subsection{Ability to handle international flights}

The ability to handle international flights does not determine the predominant interest in the infrastructure and, as a result, it does not determine the regime under which it shall be exploited.

Special purpose airports may or may not be international depending on their functional roles. The Punta Cana International Airport, whose special purpose is to serve the tourism industry, is international; the Usiminas Airport serves the business unit and is considered domestic.

Reliever airports that provide alternatives to a congested area may or may not be international. For example, London City International Airport, which serves the general and executive aviation, is international. Lanseria International Airport, which is an alternative to the main Johannesburg airport, operates domestic scheduled flights only, even though it is apt to handle international flights.

\subsection{Single or Additional Airports}

In many cases, special purpose airports, such as the Usiminas Airport or the Monte Dourado Airport, precede conventional airports. They supply a seasonal or insufficiently profitable demand to regular commercial aviation until regional development reaches levels compatible with the provision of services under public regime. They create the economic flow that generates development and airport demand. In other cases, reliever airports are secondary airports in a region where the infrastructure is congested.

In each example, the fact that an airport is the single or an additional airport in a certain region is irrelevant to determine the prevailing interest over its exploitation. 


\section{The evolution of the provision of airport services and the different types of grants for its exploitation}

Prazeres suggests that the types of grants for exploiting airport services go through a transformation or evolution that consists of three subsequent phases. In each phase the government adds less invasive types of grants. Each phase does not replace entirely the type of exploitation of the previous one, but rather adds an addition type of grant increasing the breadth and the flexibility of the portfolio. The author cites Article 36 of the Brazilian Aeronautical Code to confirm his proposition:

\footnotetext{
"Art. 36. The public aerodromes will be built, maintained and exploited:

I-directly, by the Union;

II - by specialized companies of Indirect Federal Administration or its subsidiaries linked to the Ministry of Aviation;

III - under agreements with states or municipalities;

IV-by lease or permits."
}

The first three items correspond to the first phase when the Government has a de facto monopoly over the provision of airport services, whether directly (Item I), or through Stateowned entities or federation units and municipalities (Items II and III).

The fourth item sets the actual grant of the infrastructure exploitation to the private sector. This item corresponds to the second and third phases.

In the second phase, the de facto monopoly is broken and the government grants the private sector the right to exploit the airports by means of leases. The lease is exploited under public regime, so the government keeps a relevant power to intervene over the provision of the granted services.

In the third phase, Prazeres suggests the emergence of permits, in order to promote greater efficiency in the provision of airport services. The emergence of the permits as instruments of grant for airport exploitation is due to the increase in demand for air transportation that results from regional economic development.

The demand for air transportation is a function of the demographics of the region and its economic activity. In the same way the development of economic activity occurs gradually, 
the demand for air travel will not grow suddenly to a size that makes it feasible to maintain a regular route of commercial aviation. The first events of demand-increase may occur in isolated sectors like those in seasonal or low density routes, such as tourism and cargo.

\subsection{Temporal or Situational Approaches}

The use of various mechanisms to grant exploitation of airport services can be examined through a temporal approach and/or a situational approach.

\subsubsection{Temporal Approach}

In the temporal approach, the different mechanisms of exploitation set in Article 36 of the Brazilian Aeronautical Code would be used in sequence to the extent of the economic development and the demand for air services and airport expansion. Figure 1 below depicts this proposition.

Figure 1 - Types of Grant

\section{Regulatory Intervention vs. Sector Development}

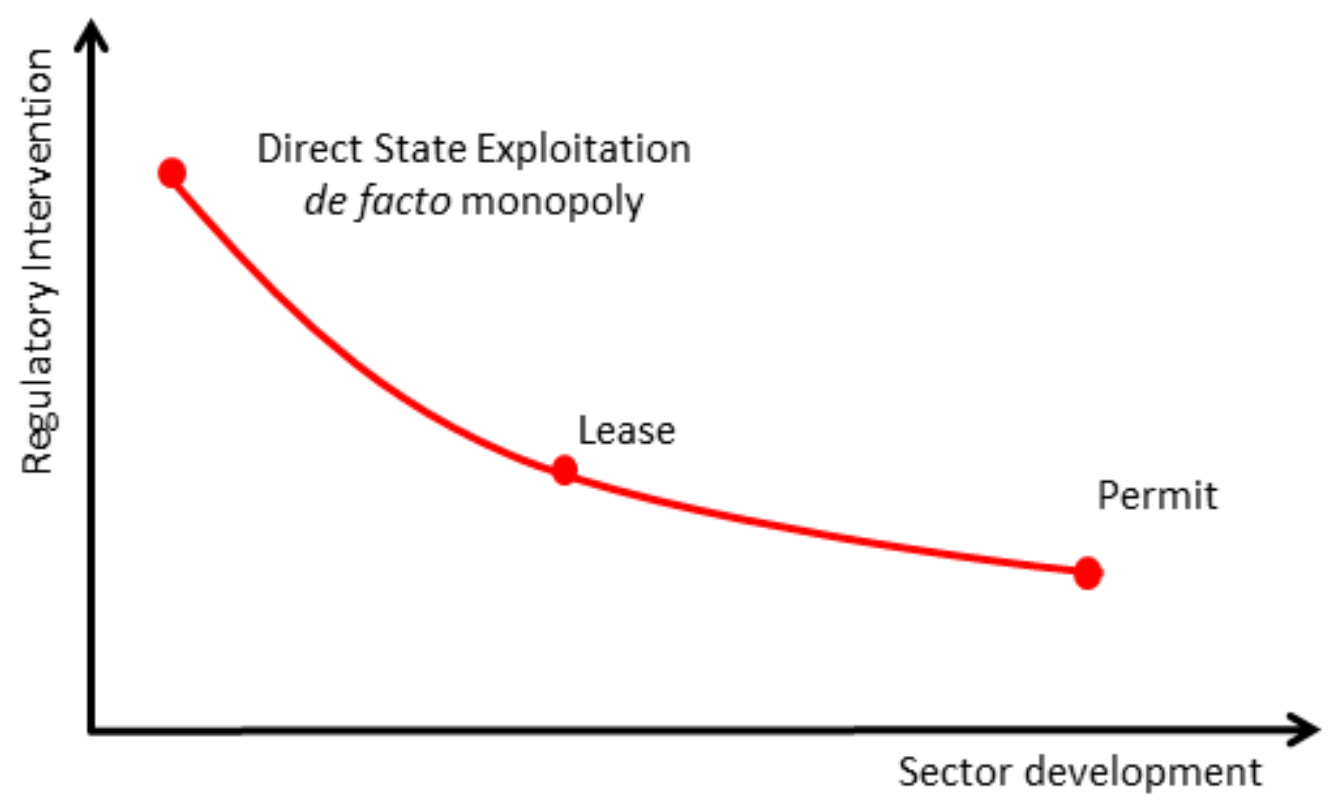

Source: Prazeres (2011, p. 67). 


\subsubsection{Situational Approach}

In the situational approach, the use of different mechanisms of exploitation provided in Article 36 of the Brazilian Aeronautical Code is the result of public policies that use an optimal combination of grant types to offer the most efficient portfolio of airport services to the population.

The temporal and situational approaches are not mutually exclusive. The temporal approach will always be used because the profile and development of the market play an important role in the choice of exploitation regime. The situational approach adds flexibility by using all types of grants to complement each other.

\section{Conclusion}

The level of economic development of a certain location is mirrored by the provision of airport services. Economic development creates and increases demand for air transport services, and consequently, for airport infrastructure.

The more developed and complex the airport system of a country, the more important it becomes to have exploitation regimes with different levels of regulatory intervention. The diversity of the types of grants provided for in the law brings flexibility to the public policy to offer the best portfolio of airport infrastructure to the population as a whole and to specific sectors.

Brazil faces an extreme lack of airport capacity that can be reduced through public policies that use the option provided for by Brazilian law to permit the exploitation of airports in which the prevailing interest is private. "The permitted airport is exploited at the risk of the private sector and does not create unnecessary and costly interference of the State in the provision of its services" (Borges, 2007).

Along the same lines, Payson e Steckler recommends that decisions made by the Public Sector about the type of grant ought to take into account the intended level of regulatory intervention to be imposed over the airport, according to its unique circumstances, and through a case by case analysis. 
Brazilian law allows the grant of exploitation of airport services by means of leases or permits. The difference between the types of grants is the regime under which the exploitation will occur: public or private, respectively.

There is public interest in all airport undertakings that serve the public and not its owner exclusively but the degree of interest varies according to the features of the business being undertaken.

The assessment of the prevailing interest in an airport cannot be based on its capacity or operational features. The public interest prevails when the airport creates universal value of use to the country and not a marginal or additional value of use to a specific sector or community.

The type of grant chosen depends on the interest that prevails in the exploitation of the airport: if public, the grant will be a lease exploited under the predominance of public regime; if private regime predominates, the grant will be a permit.

The different types of grants are not independent of each other and should coexist; the optimal granting policy is an ideal combination of types of grants directly related to the diversification of the airport services and the different levels of regulatory intervention that they require. 


\section{References}

Aragão, A. S. de. (2009) O Conceito de serviços públicos no direito constitucional brasileiro. Revista Eletrônica de Direito Administrativo Econômico - REDAE, Salvador, Instituto Brasileiro de Direito Público, $\mathrm{n}^{\circ}$. 17, February/March/April. Available at: http://www.direitodoestado.com.br/redae.asp. Access on September 12, 2011

Binger, K. (1999) CPH: Copenhagen Airports A. S. In: Icao airport privatization seminar/forum, Guatemala. [Anais Eletrônicos], Available at: <www.icao.int/icao/en/ro/nacc/aps/10_binger.pdf>. Access on: March 24, 2011.

Borges, C. (2007) Construção de aeroportos privados: aeroportos privados como vantagem estratégica para empreendimentos hoteleiros. Revista Infra, São Paulo, ago. Available at: <http://www.revistainfra.com.br/textos.asp?codigo=8509>. Access on: April 21, 2010.

Brazil. (1988) Constituição da república federativa do Brasil. Brasília: Senado Federal.

Brazil. (2005) Lei n. 11.182, de 27 de setembro de 2005. Cria a Agência Nacional de Aviação Civil ANAC e dá outras providências. Diário Oficial da União, Brasília, Set. 28. Seção 1, p. 1.

Brazil. (1973) Lei n. 6.009, de 26 de dezembro de 1973. Dispõe sobre a utilização e a exploração dos aeroportos, das facilidades à navegação aérea e dá outras providências. Diário Oficial da União, Brasília, Dez. 28.

Brazil. (1986) Lei n. 7.565, de 19 de dezembro de 1986. Código Brasileiro de Aeronáutica. (Substitui o Código Brasileiro do Ar). Diário Oficial da União, Brasília, Dez. 19.

Brazil. (1995) Lei n. 8.987, de 13 de fevereiro de 1995. Dispõe sobre o regime de concessão e permissão da prestação de serviços públicos previsto no art. 175 da Constituição Federal, e dá outras providências. Diário Oficial da União, Brasília, Fev. 14.

Couto e Silva, A. (2009) Privatização no Brasil e o novo exercício de fuções públicas por particulares. Revista Eletrônica sobre a Reforma do Estado - RERE, Salvador, Instituto Brasileiro de Direito Público, $\quad \mathrm{n}^{\circ}$. 16, December, January, February. Available at: <http:www.direitodoestado.com.br/rere.asp>. Access on: September 12, 2011.

Espirito Santo Júnior, R. A., Prazeres, D. L. e Santana, E. M. (2010) Gerenciamento privado de aeroportos: fatores positivos e negativos no caso brasileiro. Instituto Cepta, Rio de Janeiro. Available at: http://www.intelog.net/site/popup.asp?Url=../ArtigosNoticias/Arquivos/gerenciamento privado em_aeroportos.pdf. Access on: April 21, 2011.

Farias, S. J. L. (2005) A regulação jurídica dos serviços autorizados. Rio de Janeiro: Lumen Júris.

Heinke, G. W., Wei, J. (2000) Consultancy to examine and disseminate innovative approaches to financing of initiatives such as sustainable infrastructure and building, panning, design, construction, and operation for Asia Pacific Economic Co-operation - APEC. Hong Kong: Hong Kong University of Science and Technology.

Kapur, A. (1995) Airport infrastructure: the emerging role of the private sector. World Bank Technical Paper, Washington, D.C., n. 313.

Pacheco, J. S. (2006) Comentários ao código brasileiro de aeronáutica: de acordo com as leis $n^{\circ}$ 7.565, de 19.12.1986, e $n^{o}$ 11.182, de $n^{\circ}$ 27.09.2005., 4. ed., São Paulo: Forense.

Payson, W. H., Steckler, S. A. (1992) Expanding airport capacity: getting privatization off the ground. Reason Foundation, California, n. 141, jul. 
Poole Júnior, R. W. (1994) Guidelines for airport privatization. Los Angeles-CA: Reason Foundation, Oct.

Prazeres, D. L. (2011) A exploração de aeroportos em regime privado: um ensaio para sua classificação. Brasília: Universidade de Brasília. 